\title{
Own Credit Risk Accounting, Modigliani-Miller Theorem, and the Fallacy of Counter-Intuitive Results
}

\author{
Francesco Bellandi ${ }^{1}$ \\ ${ }^{1}$ Head of Technical Accounting, Multinational, London, UK \\ Correspondence: Francesco Bellandi, Head of Technical Accounting, Multinational, London, UK. E-mail: \\ Francesco_bellandi@yahoo.com
}

Received: June 10, 2021

Accepted: July 20, 2021

Online Published: August 14, 2021

doi:10.5539/ijbm.v16n9p129

URL: https://doi.org/10.5539/ijbm.v16n9p129

\begin{abstract}
Purpose: This article tests own credit risk accounting under Modigliani-Miller theory to determine whether there is a fundamental fallacy in the unsolved issue of counter-intuitive results.

Design/methodology/approach: A system of equations derived from the MM theorem to own risk.

Findings: Solutions to the wealth transfer hypothesis. Parameters of issuer and holder that nullify own credit risk gain/loss and impairment loss/gain. A theoretical framework is developed to reconcile accounting to Modigliani-Miller theory. If the MM theory is true, as generally it is held to be, the system of equations shows that the recognition of own credit gain or loss would arise from different accounting measurement bases of liability own risk versus assets impairment, and by not reflecting the rebound effect in liability fair value measurement, in both cases not a faithfully representation of the substance of the facts and circumstances. The former would require a re-alignment between impairment and financial liability measurement rules. The latter would require a rethinking of fulfillment vs. fair value measurement to these liabilities. In addition, given the tenet that the accounting does not recognize shareholder wealth transfer, the current financial performance dilemma can be solved by recognizing in equity the concept of capital maintenance adjustment.

Originality: Rare, if not unique, innovative direct application of MM paradigm to own risk.

Implications: Significant contribution to the debate on performance and OCI, counter-intuitive results and accounting mismatch, fulfilment value versus fair value, incomplete recognition of contemporaneous asset value, and the definition of income in the Conceptual Framework.
\end{abstract}

Keywords: Modigliani-Miller, own credit risk, debt valuation adjustment, IFRS 9

\section{Background}

This work tests the International Accounting Standards Board (IASB) 2019, IFRS 9 and Financial Accounting Standards Board (FASB 2014), ASU 2016-01 accounting for a financial liability own credit risk (hereafter, own risk) under the financial theory of Modigliani and Miller, 1958 (hereafter, MM), with the objective to determine whether the foundations of that theory show a fundamental fallacy in the unsolved issue of counter-intuitive results. For this purpose, the article develops a system of equations derived from the MM theory, applies it to own risk (a rare, if not unique, innovative direct application of the MM theorem to own risk), and finds the solutions of wealth transfer hypothesis in that context. It finds implications that significantly contribute to the debate on performance, fulfilment value versus fair value, and incomplete recognition of contemporaneous asset value, highlighting a need for a critical revision of extant accounting as well as new directions of research.

In conclusion, if the MM theory is true (and it is generally held to be so), the system of equations shows that the recognition of own credit gain or loss for the financial liability issuer, as well as the corresponding impairment loss or gain for the financial asset holder, must be wrong from an economic perspective. Given the tenet that the accounting does not recognize shareholder wealth transfer, the current financial performance dilemma can be solved in two ways: either by recognizing in equity the concept of capital maintenance adjustment, or by using fulfillment value instead of fair value for such financial liabilities. In addition, if the MM theory is true, then the system of equations also shows that the definition of income in the Common Framework derived from changes in net assets as opposed to changes in net operating assets also needs to be revised. Consequently, the use of other comprehensive income (hereafter, OCI) as a way of drawing a separation at where financial performance 
ends, and consequently, the accounting mismatch are false problems, because there should be no gain or loss in profit or loss in the first place or wealth transfer should be recognized as a capital adjustment in equity.

A benefit of the article is that it provides a direction to solve long debated and still unsolved topics through basic and simple algebraical developments of the MM formulas to derive conclusions based on logical critical thinking, so the reader need not have any advanced quantitative skills. Finally, the analysis seeks to construct a model that could be of general application, without taking into consideration specific cases such as derivative liabilities, which is instead often the object of analysis by academic literature on banks debt (or debit) valuation adjustments (DVAs).

As a background, under IASB 2019, IFRS 9, an entity is permitted, not required, to irrevocably designate a financial liability as at fair value through profit or loss (hereafter, FVTPL) at initial recognition, when permitted by IASB 2019, IFRS 9, para. 4.3.5 (designation as at FVTPL of an entire hybrid contract containing embedded derivatives that are not separable) or when permitted by IASB 2019, IFRS 9 para. 4.2 .2 (i.e., when the election eliminates or significantly reduces an accounting mismatch of measurement bases of assets and liabilities, or when financial assets and financial liabilities are managed and evaluated at fair value on a group basis). If the entity elects fair value, it reports a gain from a decrease in the fair value of the financial liability that is attributable to changes in credit risk (so-called own credit risk). Following a fierce debate about this counter-intuitive result from a deterioration in credit risk in own financial liability, the IASB and the FASB have provided for the presentation of the amount of that change in fair value in other comprehensive income (hereafter, OCI) Unlike U.S. GAAP, IFRS requires recognition in profit or loss if the said treatment would create or enlarge an accounting mismatch in profit or loss (FASB 2016, ASU 2016-01, para. BC107; IASB 2019, IFRS 9 paras. 5.7.1.c, 5.7.7, 5.7.8, B5.7.6, B5.7.8; and FASB 2020, FASB ASC 825-10-45-5).

\section{Literature Review}

As IASB 2009, DP/2009/2 summarizes, several arguments have been used for or against the accounting for own risk, including counter-intuitive results, consistency between initial and subsequent fair value measurement, wealth transfer hypothesis, lack of realization due to restrictions on transfer of financial liabilities or lack of resources to buy back liabilities, and accounting mismatch.

More in particular, the accounting for own credit risk has been criticized for its counter-intuitive results, as a company gains from the deterioration of the credit quality of its financial liabilities (Chasteen et.al., 2007; European Financial Reporting Advisory Group (Efrag) 2008, DP 2008, para. 4.15; IASB 2008, DP 2008, paras. 3.31, 3.73, 3.75; IASB 2009, DP/2009/2, para. 48; Gaynor et al., 2011; IASB 2016, IASB 2016, IFRS 13, para. BC95; IASB 2019, IFRS 9, para. BCE.41).

The debate has also been expanded to whether the fair value option for financial liabilities is suitable, as well as whether fair value is an appropriate measurement base for such instruments (IASB 2016, IFRS 13, para. BC95; IASB 2019, IFRS 9, para. BCZ5.31). Bradbury, 2008 discusses whether fair value should include own credit risk. Fair valuation of company's own debt was one of the reasons for the EC carve-out of IAS 39, as EC 1978, Directive 78/660/EEC, Article 42a did not permit fair valuation of loans and receivables originated by the company and not held for trading purposes. Basel III requires banks to eliminate the effect of DVA on their regulatory capital.

In the stream of the wealth transfer hypothesis, Merton, 1974 sees borrowing entailing a written put option by debtholders to equity holder at the liability face amount and asserts the validity of the MM theorem in the presence of bankruptcy. Heckman, 2004 argues for a default free liability valuation and that the "borrowing penalty" is a loss at inception. Chasteen et al., 2007 conceive such a penalty as an "insolvency put" of the owners to account for directly in equity.

Chung et al., 2012 and Cedergren et al., 2019 report a positive relationship between DVAs and stock returns, which however weakens as the level of unrecognized assets increases. Barth et al., 2008 find that counterintuitive income effects are primarily attributable to incomplete recognition of contemporaneous asset value changes. Cardoso Fontes et al., 2018 find an association between fair value measurement of bank assets, and even more own risk gains and losses, and lower information asymmetry. On the other hand, Chung et al., 2012 find a negative association of own risk gains or losses with future stock returns which suggests that gains are eventually not realizable or market overreaction to their recognition. Bischof et al., 2014 find that most financial analysts exclude banks' own credit risk effects from reported earnings. Dong et al., 2016 find evidence of exercise of discretion over DVA to smooth earnings for a sample of publicly traded European banks during 2008-2013. Lin et al., 2019 conclude that superior ability of managers to estimate own credit risk rather than determinants of the credit quality explain DVAs for surveyed U.S. bank holding companies. 


\section{Research Questions}

The review of academic literature shows that contributions are mostly on empirical evidence and valuation implications. There are contrasting opinions as to whether there should be a profit impact reported from own risk. On the other hand, professional accounting literature has been unfruitful in reaching a consensus on the appropriateness of fair value measurement for such financial liabilities, as well as on the concept of financial performance and whether own risk gains or losses should be part of it (Bellandi, 2012). Although there are some academic contributions to the connections between MM theory and DVA, generally such a theory is not directly applied to own risk. In line with the MM theory in perfect markets, an increase in the risk of debt would be expected not to affect the market value of the firm, to the extent that the reduction in the market value of equity arising from an increase in the rate of return on equity required by shareholders for higher equity risk counterbalances the positive effect on the debt side. This article takes a fresh approach by directly testing the economic substance of own risk gains or losses through the MM theory. As the conclusions of this exercise diverge from extant accounting, it builds a conceptual framework to understand why. It then derives what the ramifications for accounting research could be. The research questions are as follows:

-research question No. 1: what are the findings of applying the MM model to financial liability own credit risk?

-research question No. 2: can a theoretical framework be built to reconcile accounting to MM theory?

\section{Research Method}

This article applies the basic MM theory equations of the value of the firm to both an issuer of a financial liability with own credit risk and the counterparty holder. The key assumptions of the workings are the following.

There are two companies, where one is the issuer of a financial liability that is subject to own risk (Company 1) and the other is the holder of the same instrument held as a financial asset (Company 2).

Total financial liabilities of Company 1 equal total financial assets of Company 2, as Company 2 is the holder of all the financial liabilities of Company 1. As the debtholder of Company 1 is Company 2, if Company 1's financial liability own risk increases, Company 2 gets its financial asset impaired.

Under IASB 2019, IFRS 9, para. B5.7.13 own credit risk refers to the credit risk of the specific liability, not the creditworthiness of the issuer. Conversely, the MM model applies to the entity as a whole. Therefore, it is assumed that the financial liability subject to own risk is the only financial liability of Company 1 and the only financial asset of Company 2. This neutralizes this accounting convention and places the accounting and finance workings at the same level.

Company 1's financial liability that is subject to own risk has no 'economic relationship', as defined in IASB 2019, IFRS 9, with any other of its assets. This is to exclude specific accounting implications, as noted below, to distort the analysis.

In terms of notations, $\mathrm{D}$ stands for debt, $\mathrm{E}$ for equity, $\mathrm{A}$ for assets. 1 indicates Company 1, and 2 Company 2, zero ${ }_{0}(0)$ indicates value before a change in own credit risk, one $\left.{ }_{1}\right)$ indicates value after that change, $\mathrm{R}$ stands for a change of value of D due to own credit risk, I (impairment) stands for a change in value of the financial asset of Company 2 (as assessed by market participants) due to the change in own risk of the corresponding liability of Company 1 .

Two scenarios are analyzed: Scenario 1 is where in MM-type formulas A is defined as net operating assets (hereafter NOA), so that the financial liability is not part of A and a change in the financial liability own risk changes the value of D but does not affect the value of A. Scenario 2 is where A is defined as net assets (i.e., total assets minus total liabilities), so that the financial liability is part of A and a change in the financial liability own risk changes the value of A. As it will soon become clear, the two scenarios have an implicit meaning. Scenario 1 corresponds to the view in the MM approach that a change in the value of a financial liability changes the value of D but does not affect the value of the firm. Scenario 2 corresponds to the assumption in the accounting for own risk gain or loss, whether recognized in profit or loss or OCI, that a change in the value of a financial liability does affect A, i.e., the performance of the firm. The article develops the MM equations in all permutations of these scenarios and investigates the consequences from market participants perspective as compared with the accounting. It may be argued that from a financial accounting/reporting perspective, this distinction has no meaning, as the distinction is generally made by financial statement users in certain contexts for financial analysis not financial accounting to focus on operating versus financing decisions. This article uses this argument to claim that the Conceptual Framework view of income and expenses based on changes in net assets leads to fallacies and dilemmas as for the case of own risk credit gains and losses. This is because 
financial assets and liabilities are considered part of net assets in the Conceptual Framework but would not be in a MM paradigm. What this paper contends is that the current accounting for own credit risk is based on a definition of income and expense in the Conceptual Framework that follows from the classification of items as assets and liabilities irrespective of whether change in those items arises from a change in asset productivity that causes a change in entity's value or riskiness. By comparing NOA with net assets, it shows that using what today is a classification convention in financial statement analysis as a definitory foundation in income and expense measurement would make accounting match the MM tenet that financing transactions not backed up by change in asset's value should not change the value of the firm (including in the form of a change in retained earnings or accumulated other comprehensive income).

Under an economic valuation by market participants, the formulas for impairment work in both directions, although accounting wise an impairment gain would be recognized only to the extent that favorable changes represent a reversal of risk that was previously recognized as an unfavorable change (IASB 2019, IFRS 9, para. BC5.210).

The MM framework works in terms of market value, while IFRS 9 treatment of own credit risk applies to a financial liability measured at fair value. The accounting concept of fair value is larger than market value and subsumes it. In IASB 2018, CF 2018, para. 6.11, fair value is a type of current value. Hence, this difference does not affect the analysis and conclusions.

Finally, to set a level playing field for both accounting and MM theory, the absence of restrictions is assumed. The reason is twofold. First, this permits to perform the test under the IASB and FASB tenet that, when quoted prices are not available, the fair value of a liability equals the fair value of an asset whose features mirror those of the liability (IASB 2016, IFRS 13, paras. 40, BC88-BC89; FASB 2020, FASB ASC 820-10-35-16B, 16D). Second, while most current developments of the MM theory focus on translating its initial simple deterministic settings into stochastic economies (i.e., a development in finance), the incremental contribution of this work is a development in accounting theory, not in finance, about whether accounting reflects the substance of the transaction as depicted in the frictionless, perfect economy of the MM theory when accounting conventions are removed. The benefit of this is not to calibrate accounting to a frictionless a perfect world that does not exist but to purify reality to boil down to the substance of the transaction to see whether the accounting faithfully reflects it. Once the fundamental step in establishing the substance is done, this does not mean that the MM tenet of irrelevance of financing decisions should overwrite the accounting for own credit risk if those decisions are found to be relevant for practical reasons.

This article does not intend to address how MM theory should work in the real world, but on the contrary get rid of accounting complications and conventions in the "real world" to test whether the basic principles behind accounting for own risk really reflect the underlying economic phenomena revealed by the MM theory. This moves along the IASB's long-standing view that accounting should present information to users of financial statements that is neutral and portrays the economic characteristics at the reporting date (IASB 2019, IFRS 9, para. BCE.94). So, the article does not try to eliminate arbitrage where the MM theory suggests that this is part of the economic substance, on the contrary it tests whether such arbitrage is captured by accounting as a pure MM theory suggests.

\section{Results}

\subsection{Direct, Indirect, and Re-Bounce Effects}

This section develops the fundamental equations of the different combinations of scenarios.

In all cases, the value of the firm is equal to the value of debt plus value of equity.

$$
\begin{aligned}
& \text { For Company 1: } \mathrm{V} 1 \mathrm{~A}_{0}=\mathrm{V}_{1} \mathrm{D}_{0}+\mathrm{V} 1 \mathrm{E}_{0} \text {, and } \mathrm{V} 1 \mathrm{~A}_{1}=\mathrm{V} 1 \mathrm{D}_{1}+\mathrm{V} 1 \mathrm{E}_{1} \\
& \text { For Company 2: } \mathrm{V} 2 \mathrm{~A}_{0}=\mathrm{V} 2 \mathrm{D}_{0}+\mathrm{V} 2 \mathrm{E}_{0} \text { and } \mathrm{V} 2 \mathrm{~A}_{1}=\mathrm{V} 2 \mathrm{D}_{1}+\mathrm{V} 2 \mathrm{E}_{1}
\end{aligned}
$$

Company $1 /$ Scenario 1

Direct effects: If financial liabilities are not considered part of A, defined as NOA in scenario 1, an increase in own risk determines an increase of the cost of $\mathrm{D}$ and therefore a decrease in market value of debt as assessed by market participants

$$
\mathrm{V} 1 \mathrm{D}_{1}=\mathrm{V} 1 \mathrm{D}_{0}-\mathrm{R} \text {, where } \mathrm{R} \text { is own risk gain or loss }
$$

As $\mathrm{D}$ is no part of NOA, there is no change in A, unless the increase in own risk is driven by a decline in the ability of the entity's assets to generate cash. In this case

$$
\mathrm{V} 1 \mathrm{~A}_{1}=\mathrm{V} 1 \mathrm{~A}_{0}-\mathrm{I}
$$


Under accounting, D decreases because its fair value decreases and E increases simply because of the corresponding own risk gain R. IASB 2019, IFRS 9 records the decrease in value of D by R as OCI as part of the statement of comprehensive income, which translates into an increase in E. However, E also decreases because of $\mathrm{I}$. If the accounting records $\mathrm{R}=-\mathrm{I}$ as it is from an economic perspective, accounting $\mathrm{E}$ does not change and there is no gain or loss. If accounting does not record I or record R differently from -I because of different measurement attributes, the is an accounting (not economic) gain of loss in $\mathrm{E}$ for the gap

$$
\mathrm{V} 1 \mathrm{E}_{1}=\mathrm{V} 1 \mathrm{E}_{0}+\mathrm{R}-\mathrm{I}
$$

Indirect effects: As an indirect effect, under a pure MM theory, the increase in risk of D has the consequence of increasing the risk of $\mathrm{E}$ and hence the cost of $\mathrm{E}$, as equity holders demand a higher return on equity, which decreases the value of E. U stands for this effect, where U means "unrecognized" in Company 1's financial statements under extant accounting standards. As this is a remeasurement in market value of equity which does not occur through a transaction with the company, the accounting does not record it. The net effect is a matter of specific circumstances. If the directional effects are equal and opposite, E would not change.

$$
\mathrm{V} 1 \mathrm{E}_{1}=\mathrm{V} 1 \mathrm{E}_{0}+\mathrm{R}-\mathrm{I}-\mathrm{U}
$$

Re-bounce effects: The change in value of $\mathrm{E}$ overall because of the combined impact of direct and indirect effects would be translated in a further adjustment to $\mathrm{D}$ to make $D+E=A$. By denoting this re-bounce effect after applying the MM theory as $\mathrm{U}^{*}$, This is a wealth transfer between stockholders and bondholders that is not recorded by the accounting

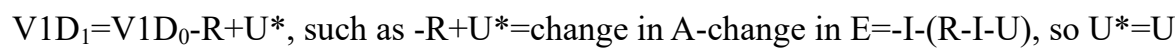

There may be two cases where there would be no change in $\mathrm{D}$. The first is where own risk is not driven by a change in the value or riskiness of assets (no change in A). Although outside the scope of the algebraic presentation, an explanation of this may be that market participants might not attach value to the change in D due to own risk, for example because deemed to be temporary and not rooted in a real change in value of assets. The

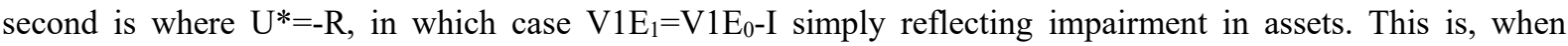
looking at Company 1 only from market participants' eyes, own risk does not affect D (and E) under scenario 1 to the extent that the direct and rebound (indirect) effects cancel out. In conclusion, accounting gain or loss would arise from different measurement bases of liability own risk versus assets impairment, and by not reflecting the rebound effect in liability fair value measurement, in both cases not a faithfully representation of the substance of the facts and circumstances.

\section{Company $1 /$ Scenario 2}

Direct effects: As the financial liability is considered part of A, which under this scenario is defined as net assets, the increase in risk of the financial liability increases the value of $A$ by an amount $R$, such that

$$
\mathrm{V} 1 \mathrm{~A}_{1}=\mathrm{V} 1 \mathrm{~A}_{0}-\mathrm{I}+\mathrm{R}
$$

with a corresponding gain in $\mathrm{E}$, such that

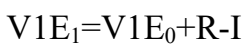

As per Scenario 1, if accounting does not record I or record $\mathrm{R}$ differently from -I because of different measurement attributes, the is an accounting (not economic) gain of loss in $\mathrm{E}$ for the gap.

Indirect effects. By looking at Company 1 only, there is no indirect change in required cost of equity under MM theory because there is no change in $\mathrm{D}$, and the own risk gain is effectively a gain in equity, as a direct effect. This would mean that there is a transfer of wealth between debtholders and shareholders, which in this case is recorded in company's financial statements because it is occurring through the company.

Re-bounce effects: If the analysis stopped here, the conclusion of scenario 2 would conflict with that of scenario 1. If instead market participants are not misled by accounting classifications, they assess net debt risk in the same way irrespective of the classification of financial instruments. This brings the case back to the reasoning under scenario 1 , with a decrease of E, denoted as U.

$$
\mathrm{V} 1 \mathrm{E}_{1}=\mathrm{V} 1 \mathrm{E}_{0}+\mathrm{R}-\mathrm{I}-\mathrm{U}
$$

After all, however classified, the risk of the net debt has increased, so shareholders must demand a higher required cost of equity. This is not recorded in financial statements because not occurring through the company. The value of $\mathrm{E}$ overall must change only by $-\mathrm{I}$ because there is no change in $\mathrm{D}$ under scenario 2 , and by definition $D+E=A$. $\mathrm{U}^{*}$ denotes this re-bounce effect after applying the MM theory. As the change in value of the financial liability was reported as $\mathrm{A}$, it must be

$$
\mathrm{V} 1 \mathrm{~A}_{1}=\mathrm{V} 1 \mathrm{~A}_{0}-\mathrm{I}+\mathrm{R}-\mathrm{U}^{*}
$$


Then for Company 1, the conclusions of Scenario 2 are the same as per Scenario 1.

Company $2 /$ Scenario 1

Direct effects: For Company 2, if the financial asset is impaired and under scenario 1 financial assets are not considered part of A (defined as NOA) but reported in D, the economic loss assessed by market participants for the financial asset increases the value of net debt $\mathrm{D}$ (note that this is a reduction in a financial asset, hence represented as an increase in net debt D). We denote the change as I, where I stands for impairment.

$$
\mathrm{V} 2 \mathrm{D}_{1}=\mathrm{V} 2 \mathrm{D}_{0}+\mathrm{I}
$$

As there is no change in value of A for Company 2 (financial assets not being defined as part of A), the increase in $\mathrm{D}$ should fully translates in a decrease in the value of $\mathrm{E}$.

$$
\mathrm{V} 2 \mathrm{E}_{1}=\mathrm{V}_{2} \mathrm{E}_{0}-\mathrm{I}
$$

Indirect effects: MM theory tells us that an increase in risk and cost of debt would trigger an increase in required return and cost of equity of Company 2, which would reduce the value of E even more. We assume that this effect also occurs at net debt level, because the total risk of net debt financing has increased to the eyes of shareholders. The risk of gross debt to debtholders has not changed, but the risk of collecting financial assets has increased. If the entity cannot collect financial assets for the full amount, it would need to get additional external debt, so the net debt risk also increases because of the financial liability component of it. This reduction in value of $E$ may be on top of the accounting reduction in $E$ measured before as a direct effect if the increase in risk of equity makes $\mathrm{E}$ decrease more than proportionally. This additional decrease, denoted as $\mathrm{N}$, is a change in value which does not occur through the company, but it is a market reaction that drives a remeasurement in equity, so the accounting does not record it. In essence, there may be two effects for Company 2: an impairment due to deterioration of the holder's financial asset because of the issuer's own liability risk, and a further deterioration of the holder's net debt risk to the extent the impairment also deteriorates the debt capacity debt of Company 2.

$$
\mathrm{V} 2 \mathrm{E}_{1}=\mathrm{V} 2 \mathrm{E}_{0}-\mathrm{I}-\mathrm{N}
$$

Re-bounce effects: By substituting formulas,

$$
\mathrm{V}_{2} \mathrm{D}_{0}+\mathrm{I}+\mathrm{V} 2 \mathrm{E}_{0}-\mathrm{I}-\mathrm{N}=\mathrm{V} 2 \mathrm{~A}_{1}
$$

This seems to show that $\mathrm{A}$ also decreases by $\mathrm{N}$, but this cannot be because the financial asset is not part of $\mathrm{A}$ in scenario 1 to justify a decrease in $\mathrm{A}$, so there must be an offsetting increase, denoted as $\mathrm{N}^{*}$, such that

$$
\mathrm{V} 2 \mathrm{~A}_{1}=\mathrm{V} 2 \mathrm{~A}_{0}-\mathrm{N}+\mathrm{N}^{*}
$$

Now it is to be determined where the other leg of the equation sits, whether in $\mathrm{E}$ or $\mathrm{D}$.

Base view: Based on this view, there must be an increase in $\mathrm{E}$, so that changes in $\mathrm{E}$ offset changes in $\mathrm{D}$

$$
\mathrm{V} 2 \mathrm{E}_{1}=\mathrm{V} 2 \mathrm{E}_{0}-\mathrm{I}-\mathrm{N}+\mathrm{N}^{*}
$$

Under this view, the accounting (by recognizing only I) would tell the truth even after applying a MM-type model. Note that the same result would be obtained if $\mathrm{D}$ also decreased by $\mathrm{N}$ due the indirect effect and then increased by $\mathrm{N}^{*}$ as such an effect was deemed to be temporary.

Alternative view: If the other leg is in $\mathrm{D}$, it would be

$$
\mathrm{V} 2 \mathrm{D}_{1}=\mathrm{V} 2 \mathrm{D}_{0}+\mathrm{I}+\mathrm{N}^{*}
$$

$\mathrm{N}^{*}$ would not refer to the financial asset, but to the financial liabilities of Company 2 . If the value of its debt increases without changing its nominal value, it means that the cost of debt has decreased because its risk has decreased. In essence, the market must deem the previous effect on D as temporary, because the market sees the impairment to be transitory as well as not further affecting the entity's debt capacity.

For Company 2 there is an impairment loss or gain in $\mathrm{D}$ and $\mathrm{E}$ for scenario 1 under a base view, while a double dip under an alternative view. This is an apparent asymmetry when contrasted to Company 1, which the next paragraph will solve.

\section{Company $2 /$ Scenario 2}

Direct effects: Under scenario 2 for Company 2, if the financial asset is impaired, the economic loss as assessed by market participants (i.e., as a result of the change in the market value of the financial asset) reduces the value of the firm, according to the assumption that a financial asset is part of A (defined as net assets). "I" stands for this change, so that

$$
\mathrm{V}_{2} \mathrm{~A}_{1}=\mathrm{V} 2 \mathrm{~A}_{0}-\mathrm{I}
$$


This does not affect the debtholders of that company (by definition, debt of Company 2 is unaffected), therefore the decrease in value of A must fully translate in decrease in the value of $E$.

$$
\mathrm{V} 2 \mathrm{E}_{1}=\mathrm{V} 2 \mathrm{E}_{0}-\mathrm{I}
$$

\section{Indirect effects:}

Base view. There is no change in required cost of equity under MM theory because there is no change in cost of debt. By looking at Company 2 only, as the financial asset is not classified as D, no indirect effect under MM theorem would apply, and impairment would effectively be a loss in equity, as a direct effect of the impairment loss.

Alternative view: Alternatively, as market participants are expected not to be misled by accounting classifications, they would assess net debt risk in the same way, irrespective of the classification of financial instruments. This brings this case back to the reasoning under scenario 1 , where equation 10 was

$$
\mathrm{V} 2 \mathrm{E}_{1}=\mathrm{V} 2 \mathrm{E}_{0}-\mathrm{I}-\mathrm{N}
$$

The next step uses this formula to derive the re-bounce effect.

Re-bounce effects:

Base view. No effect, as before.

Alternative view: As D is not affected under scenario 2, equation (21) implies that

$$
\mathrm{V} 2 \mathrm{~A}_{1}=\mathrm{V} 2 \mathrm{~A}_{0}-\mathrm{I}-\mathrm{N}^{*}
$$

For Company 2 there is an impairment loss or gain in $\mathrm{A}$ and $\mathrm{E}$ for scenario 2 under a base view, while a double dip under an alternative view. This is an apparent asymmetry when contrasted to Company 1 , which the next paragraph will solve.

\subsection{Combining the Issuer and the Holder of the Financial Instrument}

The analysis continues by combining the two companies and the two scenarios, on the assumption that the financial asset of Company 2 is the financial liability of Company 1 because the only debtholder of Company 1 is Company 2, so the change in value of the financial liability of Company 1 must be equal to the change in value of D of Company 2 under scenario 1 and to the change in value of A of Company 2 under scenario 2 .

\section{If both companies use scenario 1}

Base view:

As explained, it is assumed that $\mathrm{V} 2 \mathrm{D}_{1}=-\mathrm{V} 1 \mathrm{D}_{1}$. As $\mathrm{V} 1 \mathrm{D}_{1}=\mathrm{V} 1 \mathrm{D}_{0}-\mathrm{R}+\mathrm{U}^{*}$, then $\mathrm{V} 2 \mathrm{D}_{1}=-\mathrm{V} 1 \mathrm{D}_{0}+\mathrm{R}-\mathrm{U}^{*}$. As $\mathrm{V} 2 \mathrm{D}_{1}=\mathrm{V} 2 \mathrm{D}_{0}+\mathrm{I}$, then $-\mathrm{V} 1 \mathrm{D}_{0}+\mathrm{R}-\mathrm{U}^{*}=\mathrm{V} 2 \mathrm{D}_{0}+\mathrm{I}$. As V2 $\mathrm{D}_{0}=-\mathrm{V} 1 \mathrm{D}_{0}$, then

$$
\mathrm{I}=\mathrm{R}-\mathrm{U}^{*}
$$

Alternative view

$\mathrm{V} 2 \mathrm{D}_{1}=-\mathrm{V} 1 \mathrm{D}_{1}$. As $\quad \mathrm{V}_{1} \mathrm{D}_{1}=\mathrm{V} 1 \mathrm{D}_{0}-\mathrm{R}+\mathrm{U}^{*}$, then $\quad \mathrm{V}_{2} \mathrm{D}_{1}=-\mathrm{V} 1 \mathrm{D}_{0}+\mathrm{R}-\mathrm{U}^{*}$. As $\mathrm{V}_{2} \mathrm{D}_{1}=\mathrm{V} 2 \mathrm{D}_{0}+\mathrm{I}+\mathrm{N}^{*}$, then

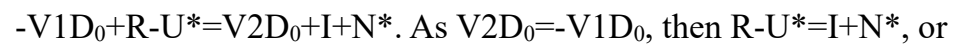

$$
\mathrm{I}=\mathrm{R}-\left(\mathrm{N}^{*}+\mathrm{U}^{*}\right)
$$

So, if $\mathrm{U}^{*}=-\mathrm{N}^{*}, \mathrm{I}=\mathrm{R}$.

If Company 1 uses scenario 1 but Company 2 uses scenario 2

\section{Base view}

$\mathrm{V} 2 \mathrm{~A}_{1}=\mathrm{V} 1 \mathrm{D}_{1}$. As $\mathrm{V} 1 \mathrm{D}_{1}=\mathrm{V} 1 \mathrm{D}_{0}-\mathrm{R}+\mathrm{U}^{*}$, then $\mathrm{V} 2 \mathrm{~A}_{1}=\mathrm{V} 1 \mathrm{D}_{0}-\mathrm{R}+\mathrm{U}^{*}$. As $\mathrm{V} 2 \mathrm{~A}_{1}=\mathrm{V} 2 \mathrm{~A}_{0}-\mathrm{I}$, then $\mathrm{V} 2 \mathrm{~A}_{0}-\mathrm{I}=\mathrm{V} 1 \mathrm{D}_{0}-\mathrm{R}+\mathrm{U}^{*}$.

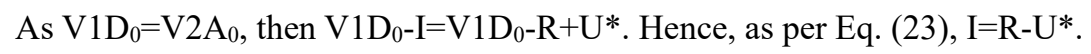

Alternative view:

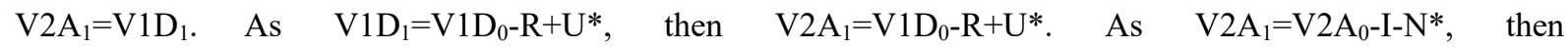

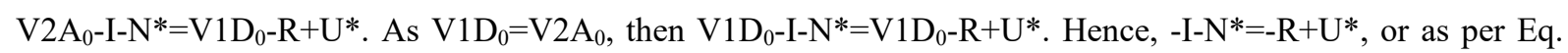
(24), I=R-( $\left.\mathrm{N}^{*}+\mathrm{U}^{*}\right)$. If $\mathrm{U}^{*}=-\mathrm{N}^{*}, \mathrm{I}=\mathrm{R}$.

If Company 1 uses scenario 2 but Company 2 uses scenario 1

Base view: 
$-\mathrm{V}_{2} \mathrm{D}_{1}=-\mathrm{V} 1 \mathrm{~A}_{1}$. As $\mathrm{V} 1 \mathrm{~A}_{1}=\mathrm{V} 1 \mathrm{~A}_{0}+\mathrm{R}-\mathrm{U}^{*}$, then $\mathrm{V} 1 \mathrm{~A}_{0}+\mathrm{R}-\mathrm{U}^{*}=\mathrm{V} 2 \mathrm{D}_{1}$. As $\mathrm{V} 2 \mathrm{D}_{1}=\mathrm{V} 2 \mathrm{D}_{0}+\mathrm{I}$, then $\mathrm{V} 1 \mathrm{~A}_{0}+\mathrm{R}-\mathrm{U}^{*}=\mathrm{V} 2 \mathrm{D}_{0}+\mathrm{I}$. As $\mathrm{V} 1 \mathrm{~A}_{0}=\mathrm{V} 2 \mathrm{D}_{0}$, then as per Eq. (23), I=R-U*.

Alternative view:

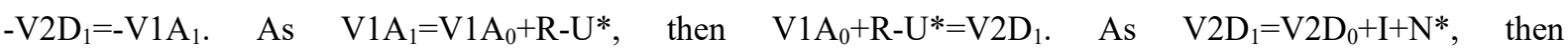
$\mathrm{V} 1 \mathrm{~A}_{0}+\mathrm{R}-\mathrm{U}^{*}=\mathrm{V} 2 \mathrm{D}_{0}+\mathrm{I}+\mathrm{N}^{*}$. As $\mathrm{V} 1 \mathrm{~A}_{0}=\mathrm{V} 2 \mathrm{D}_{0}$, hence, $\mathrm{I}+\mathrm{N}^{*}=\mathrm{R}-\mathrm{U}^{*}$, or as per Eq. (24), $\mathrm{I}=\mathrm{R}-\left(\mathrm{N}^{*}+\mathrm{U}^{*}\right)$. If $\mathrm{U}^{*}=-\mathrm{N}^{*}$, then $\mathrm{I}=\mathrm{R}$.

If both companies use scenario 2

\section{Base view}

$\mathrm{V}_{2} \mathrm{~A}_{1}=-\mathrm{V} 1 \mathrm{~A}_{1}$. As $\mathrm{V} 1 \mathrm{~A}_{1}=\mathrm{V} 1 \mathrm{~A}_{0}+\mathrm{R}-\mathrm{U}^{*}$, then $\mathrm{V} 2 \mathrm{~A}_{1}=-\mathrm{V} 1 \mathrm{~A}_{0}-\mathrm{R}+\mathrm{U}^{*}$. As $\mathrm{V} 2 \mathrm{~A}_{1}=\mathrm{V} 2 \mathrm{~A}_{0}-\mathrm{I}$, then $\mathrm{V} 2 \mathrm{~A}_{0}-\mathrm{I}=-\mathrm{V} 1 \mathrm{~A}_{0}-\mathrm{R}+\mathrm{U}^{*}$. As $\mathrm{V} 2 \mathrm{~A}_{0}=-\mathrm{V} 1 \mathrm{~A}_{0}$, then as per Eq. (23), I=R-U*.

Alternative view

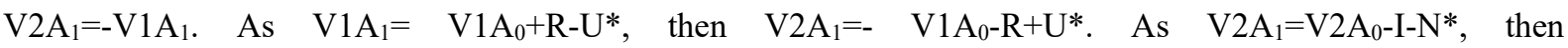
$\mathrm{V} 2 \mathrm{~A}_{0}-\mathrm{I}-\mathrm{N}^{*}=-\mathrm{V} 1 \mathrm{~A}_{0}-\mathrm{R}+\mathrm{U}^{*}$. As $\mathrm{V} 2 \mathrm{~A}_{0}=-\mathrm{V} 1 \mathrm{~A}_{0}$, then as per Eq. $(24), \mathrm{I}=\mathrm{R}-\left(\mathrm{N}^{*}+\mathrm{U}^{*}\right)$. If $\mathrm{U}^{*}=-\mathrm{N}^{*}$, then $\mathrm{I}=\mathrm{R}$.

Note that in the MM equation $V=D+E, D$ is expressed as a positive value. Therefore, if both companies use scenario 1, Company 2 shows a financial asset as negative D. If both companies use scenario 2, Company 2 shows a financial asset as negative A. If Company 1 uses scenario 1 and Company 2 uses scenario 2, both V1D and V2A have positive sign. If Company 1 uses scenario 2 and Company 2 uses scenario 1, both V1A and V2D have negative sign.

In conclusion, when considering both companies, the solutions of the systems of equations are $\mathrm{I}=\mathrm{R}-\mathrm{U}^{*}$ as per Eq. (23) under the base view and $\mathrm{I}=\mathrm{R}-\left(\mathrm{N}^{*}+\mathrm{U}^{*}\right)$ as per Eq. (24) under the alternative view. If $\mathrm{U}^{*}=-\mathrm{N}^{*}$, then $\mathrm{I}=\mathrm{R}$. If re-bound effect is ignored (i.e., only the direct and indirect effects are considered), it is easy to directly demonstrate that the solution is always $\mathrm{I}=\mathrm{R}$.

The former confirms the conclusion when looking at Company 1 only. Under the base view, impairment loss or gain in Company 2 is equal to the difference between Company 1 own risk gain or loss and Company 1 re-bounce effect. To the extent that the latter two effects cancel out there must be no impact of own risk on Company 1, and there cannot be any impact in Company 2 too. In other terms, this may happen where market participants adjust their valuation of Company 2 to offset the accounting impairment because they do not believe it is founded in the middle-long term. As explained, this may mean that fair valuation of Company 1 debt may fail to value this effect. Second, while under the base view the re-bounce effect of Company 2 is irrelevant, under the alternative view, Company 2 impairment loss or gain is equal to Company 1 own risk gain or loss less the sum of the re-bound effects in the two companies.

The analysis carries on by deriving the value of equity of Company 2 (VE2 $2_{1}$ ) from the above by finding the solutions that give $V 2 E_{l}=V 2 E_{0}$, that is, for market participants to conclude that there is no impairment loss or gain in Company 2 when they assess that own risk gain or loss of Company 1 does not affect the value of the firm. These conditions are

$$
\mathrm{R}=-\mathrm{N} \text { and } \mathrm{U}^{*}=-\mathrm{N}^{*}
$$

and

$$
\mathrm{R}=\mathrm{U}^{*}
$$

when Company 2 uses scenario 2 base view.

That shows the interaction of Company 1 in the valuation of Company 2. If the re-bounce effects of the two companies cancel out, and $\mathrm{N}$ (the indirect effect on $\mathrm{E}$ of Company 2 because of the change in Company 1 risk of D) and R (Company 1 own risk gain or loss) also cancel out, then Company 2's E does not change. There may also be another situation of indifference of Company 2's $\mathrm{E}$, that is, when $\mathrm{N}$ differs from $\mathrm{R}$ and the difference between $\mathrm{U}^{*}$ and $\mathrm{N}^{*}$ makes up such a gap. In essence, either market participants would adjust their valuation straight away through both indirect and re-bound effects, or later in the form of a re-bounce effect as they become unconvinced that there is medium-long term economic substance in the own credit risk phenomenon. Either way, market participants would not consider own risk to affect value of both Company 1 and Company 2, for example because deemed to be temporary.

The proof is below. 


\section{Both companies using scenario 1}

Base view: $\mathrm{V} 2_{2} \mathrm{E}_{1}=\mathrm{V} 2 \mathrm{E}_{0}-\mathrm{I}-\mathrm{N}+\mathrm{N}^{*}$, as $\mathrm{I}=\mathrm{R}-\mathrm{U}^{*}, \mathrm{~V}_{2} \mathrm{E}_{1}=\mathrm{V}_{2} \mathrm{E}_{0}-\mathrm{R}+\mathrm{U}^{*}-\mathrm{N}+\mathrm{N}^{*}$, or $\mathrm{V} 2 \mathrm{E}_{1}=\mathrm{V} 2 \mathrm{E}_{0}-(\mathrm{R}+\mathrm{N})+\left(\mathrm{U}^{*}+\mathrm{N}\right)$. If $\mathrm{Eq}$. (25): $\mathrm{R}=-\mathrm{N}$ and $\mathrm{U}^{*}=-\mathrm{N}^{*}$, then $\mathrm{V}_{2} \mathrm{E}_{1}=\mathrm{V}_{2} \mathrm{E}_{0}$.

Alternative view: $\quad \mathrm{V}_{2} \mathrm{E}_{1}=\mathrm{V} 2 \mathrm{E}_{0}-\mathrm{I}-\mathrm{N}, \quad$ as $\quad \mathrm{I}=\mathrm{R}-\left(\mathrm{N}^{*}+\mathrm{U}^{*}\right), \quad \mathrm{V} 2 \mathrm{E}_{1}=\mathrm{V} 2 \mathrm{E}_{0}-\mathrm{R}+\mathrm{N}^{*}+\mathrm{U}^{*}-\mathrm{N}, \quad$ or $\mathrm{V} 2 \mathrm{E}_{1}=\mathrm{V} 2 \mathrm{E}_{0}-(\mathrm{R}+\mathrm{N})+\left(\mathrm{N}^{*}+\mathrm{U}^{*}\right)$. If as per Eq. $(25): \mathrm{R}=-\mathrm{N}$ and $\mathrm{U}^{*}=-\mathrm{N}^{*}$, then $\mathrm{V} 2 \mathrm{E}_{1}=\mathrm{V} 2 \mathrm{E}_{0}$.

Company 1 uses scenario 1 and company 2 uses scenario 2

Base view: $\mathrm{V} 2_{1} \mathrm{E}_{1}=\mathrm{V} 2 \mathrm{E}_{0}-\mathrm{I}$, as $\mathrm{I}=\mathrm{R}-\mathrm{U}^{*}, \mathrm{~V} 2 \mathrm{E}_{1}=\mathrm{V} 2 \mathrm{E}_{0}-\mathrm{R}+\mathrm{U}^{*}$. If as per $\mathrm{Eq}$. (26): $\mathrm{R}=\mathrm{U}^{*}$, then $\mathrm{V} 2 \mathrm{E}_{1}=\mathrm{V} 2 \mathrm{E}_{0}$.

Alternative view: $\quad \mathrm{V}_{2} \mathrm{E}_{1}=\mathrm{V} 2 \mathrm{E}_{0}-\mathrm{I}-\mathrm{N}, \quad$ as $\quad \mathrm{I}=\mathrm{R}-\left(\mathrm{N}^{*}+\mathrm{U}^{*}\right), \quad \mathrm{V} 2 \mathrm{E}_{1}=\mathrm{V}_{2} \mathrm{E}_{0}-\mathrm{R}+\mathrm{N}^{*}+\mathrm{U}^{*}-\mathrm{N}, \quad$ or $\mathrm{V} 2 \mathrm{E}_{1}=\mathrm{V} 2 \mathrm{E}_{0}-(\mathrm{R}+\mathrm{N})+\left(\mathrm{N}^{*}+\mathrm{U}^{*}\right)$. If as per Eq. $(25)$ : $\mathrm{R}=-\mathrm{N}$ and $\mathrm{U}^{*}=-\mathrm{N}^{*}$, then $\mathrm{V} 2 \mathrm{E}_{1}=\mathrm{V} 2 \mathrm{E}_{0}$.

Company 1 uses scenario 2 and company 2 uses scenario 1

Base view: $\mathrm{V} 2_{2} \mathrm{E}_{1}=\mathrm{V}_{2} \mathrm{E}_{0}-\mathrm{I}-\mathrm{N}+\mathrm{N}^{*}$, as $\mathrm{I}=\mathrm{R}-\mathrm{U}^{*}, \mathrm{~V}_{2} \mathrm{E}_{1}=\mathrm{V} 2 \mathrm{E}_{0}-\mathrm{R}+\mathrm{U}^{*}-\mathrm{N}+\mathrm{N}^{*}$, or $\mathrm{V} 2 \mathrm{E}_{1}=\mathrm{V} 2 \mathrm{E}_{0}-(\mathrm{R}+\mathrm{N})+\left(\mathrm{N}^{*}+\mathrm{U}^{*}\right)$. If as per Eq. (25): $\mathrm{R}=-\mathrm{N}$ and $\mathrm{U}^{*}=-\mathrm{N}^{*}$, then $\mathrm{V} 2 \mathrm{E}_{1}=\mathrm{V} 2 \mathrm{E}_{0}$.

Alternative view: $\quad \mathrm{V}_{2} \mathrm{E}_{1}=\mathrm{V} 2 \mathrm{E}_{0}-\mathrm{I}-\mathrm{N}, \quad$ as $\quad \mathrm{I}=\mathrm{R}-\left(\mathrm{N}^{*}+\mathrm{U}^{*}\right), \quad \mathrm{V} 2 \mathrm{E}_{1}=\mathrm{V} 2 \mathrm{E}_{0}-\mathrm{R}+\mathrm{N}^{*}+\mathrm{U}^{*}-\mathrm{N}, \quad$ or $\mathrm{V} 2 \mathrm{E}_{1}=\mathrm{V} 2 \mathrm{E}_{0}-(\mathrm{R}+\mathrm{N})+\left(\mathrm{N}^{*}+\mathrm{U}^{*}\right)$. If as per Eq. $(25): \mathrm{R}=-\mathrm{N}$ and $\mathrm{U}^{*}=-\mathrm{N}^{*}$, then $\mathrm{V} 2 \mathrm{E}_{1}=\mathrm{V} 2 \mathrm{E}_{0}$.

Both companies using scenario 2

Base view: $\mathrm{V} 2_{1} \mathrm{E}_{1}=\mathrm{V} 2 \mathrm{E}_{0}-\mathrm{I}$, as $\mathrm{I}=\mathrm{R}-\mathrm{U}^{*}, \mathrm{~V} 2 \mathrm{E}_{1}=\mathrm{V} 2 \mathrm{E}_{0}-\mathrm{R}+\mathrm{U}^{*}$. If as per $\mathrm{Eq}$. (26): $\mathrm{R}=\mathrm{U}^{*}$, then $\mathrm{V}_{2} \mathrm{E}_{1}=\mathrm{V} 2 \mathrm{E}_{0}$.

Alternative view: $\quad \mathrm{V} 2 \mathrm{E}_{1}=\mathrm{V} 2 \mathrm{E}_{0}-\mathrm{I}-\mathrm{N}, \quad$ as $\quad \mathrm{I}=\mathrm{R}-\left(\mathrm{N}^{*}+\mathrm{U}^{*}\right), \quad \mathrm{V} 2 \mathrm{E}_{1}=\mathrm{V} 2 \mathrm{E}_{0}-\mathrm{R}+\mathrm{N}^{*}+\mathrm{U}^{*}-\mathrm{N}, \quad$ or $\quad \mathrm{V} 2 \mathrm{E}_{1}=$ $\mathrm{V} 2 \mathrm{E}_{0}-(\mathrm{R}+\mathrm{N})+\left(\mathrm{N}^{*}+\mathrm{U}^{*}\right)$. If as per Eq. $(25): \mathrm{R}=-\mathrm{N}$ and $\mathrm{U}^{*}=-\mathrm{N}^{*}$, then $\mathrm{V} 2 \mathrm{E}_{1}=\mathrm{V} 2 \mathrm{E}_{0}$.

\subsection{Expanding the Model to Nonfinancial Assets}

The analysis now moves out of the algebraic presentation and the MM theory to focus on accounting. The link with the previous section is to show how the accounting conventions distort the (accounting) substance identified so far by using the MM theory, while a postulate of accounting is to sit on the identification of the substance of a transaction, circumstances or other events.

Under IASB 2019, IFRS 9, para. B5.7.6, to test whether an accounting mismatch would be created or enlarged in profit or loss, an entity must assess whether there is an offsetting of own risk gain or loss by the change in the fair value of another financial instrument measured at fair value through profit or loss whose characteristics have an economic relationship with the characteristics of the liability, as defined in IASB 2019, IFRS 9, para. B5.7.6. First, this test only applies to an asset that is a financial asset. Second, that financial asset must be measured at FVTPL. Third, there must be an "economic relationship", be it or not due to a contractual linkage (IASB 2019, IFRS 9, paras. B5.7.11), not simply an accounting mismatch due to a choice of two different measurement bases for assets and liabilities or to an accounting imprecision in isolating the effects of credit risk (IASB 2019, IFRS 9, para. B5.7.12) or some other reason. This otherwise unqualified accounting mismatch would be for example what IASB 2019, IFRS 9, para. B4.1.29 generically calls as a relation of a liability to a financial asset or IASB 2019, IFRS 9, para. BCZ4.61 intends as a perceived economic relationship. While an unqualified accounting mismatch under IASB 2019, IFRS 9, para. 4.2.2 is one of the situations that may allow for the fair value option, an economic relationship between the characteristics of the financial liability at FVTPL and the characteristics of another financial instrument at FVTPL is required for rebutting the presentation of own risk in OCI and instead displaying it in profit or loss. An accounting mismatch that is not given by an economic relationship, or that is given by an economic relationship with a non-financial asset, or with a financial asset that is not carried at FVTPL would not qualify for the test and consequently would not bar presentation of own credit risk gain or loss in OCI.

So, it may now worth testing what happens under a MM framework when there is a situation that does not qualify for presentation in OCI. Let us first assume a nonfinancial asset, for example a license (an intangible asset) that is subject to an auction, for which therefore it would be possible to determine a fair value under IASB 2016, IFRS 13, and for which however the entity does not use the revaluation method under IASB 2018, IAS 38. The license has a license fee attached to it due to the government or authority that qualifies as a contractual financial liability, which we assume the entity measures at FVTPL. Of course, in the real word, the entity would be expected not to opt for fair value for such a liability as this would cause an accounting mismatch with the asset, which is carried at cost. The first requirement in IASB 2019, IFRS 9, para. 4.2.2. would not be met, because through the fair value option the entity would create, not eliminate, or reduce an accounting mismatch. 
However, the entity would still be permitted to make such an election by the group fair value management provision in IASB 2019, IFRS 9, para. 4.2.2.b, should this be the case. Let us also assume that under the respective standards the units of account for recognition are the intangible asset and the financial liability, separately. It is evident that there may be an economic relationship between the fair value of the asset and the fair value of the attached financial liability, as they are linked by the regulatory authority or contractual agreement as well as according to market participants valuations, such as in auctions. However, by not being a financial asset, the relationship between the license intangible asset and the license fee liability does not qualify as an economic relationship for recognizing a change in own risk of the financial liability in profit or loss. Here, we have two gaps. First, under a MM approach a change in the market value of an asset, even a nonfinancial asset, would instead trigger a change in value of the firm, while accounting wise the change in the fair value of the asset is not recognized under IASB 2018, IAS 38 (as the entity does not use the revaluation model). This comes down to the conclusion above on the need for a re-alignment between impairment and financial liability measurement rules. Second, under IASB 2019, IFRS 9 a gain or loss due to own risk would be recognized in OCI, whereas the previous analysis has shown that under certain circumstances it would not affect the value of the firm. The conclusion here is that the accounting debate has focused on where to present certain gain or losses (i.e., the classification as profit or loss or other comprehensive income) to solve the counter-intuitive gain or loss issue instead of determining whether and when those gains or losses really exist, a question to which the answer is provided by looking at the substance of the transaction under finance theory, as this article has shown.

\section{Discussion}

\subsection{Contribution to Prior Research on Counter-Intuitive Results}

Paragraph 5.1 proves that, when looking at Company 1 only from market participants' eyes, own risk does not affect D (and E) to the extent that the direct and rebound (indirect) effects cancel out. Under those conditions, there is no impact on the value of the firm of the issuer of the financial liability. In conclusion, accounting gain or loss would arise from different measurement bases of liability own risk versus assets impairment, and by not reflecting the rebound effect in liability fair value measurement, in both cases not a faithfully representation of the substance of the facts and circumstances. In other terms, own credit risk of financial liabilities and impairment of financial assets should not trigger a change in the value of the firm under a MM-type pure view because only a change in A must cause a change in the value of the firm, unless there is a change in asset's value. However, this change also produces changes in D's and in E's values that are not captured by the accounting and that under circumstances cancel out. This goes in the same direction as some empirical evidence like in Chung et al. (2012). It answers the key objective of this article to determine whether the foundations of that theory show a fundamental fallacy in the unsolved issue of counter-intuitive results.

\subsection{Contribution to the Wealth Transfer Hypothesis and Debate on Market Perceptions}

Paragraph 5.2 combines the two companies and finding the solutions of the system of equations that make own risk indifferent to both companies. It also finds the equilibrium solutions that give $V 2 E_{1}=V 2 E_{0}$, that is, for market participants to conclude that there is no impairment loss or gain in Company 2 when they assess that own risk gain or loss of Company 1 does not affect the value of the firm. Please refer to the full explanation in that paragraph. This explains that market participants would adjust their valuation of Company 2 straight away to offset the accounting impairment, or later in the form of a re-bounce effect as they become unconvinced that there is medium-long term economic substance in the own credit risk phenomenon.

Those formulas represent a wealth transfer between shareholders and debtholders, for which this article contributes significantly to prior literature in finding a formula. It also contributes, even if this is outside of the MM theory, to the literature on market perceptions of gains that are eventually not realizable or market overreaction to their recognition.

\subsection{Contribution to the Debate on Performance, OCI, and the Definition of Income}

The system of equations has used as a tool the classification of a financial liability or financial asset outside or within A, i.e., using scenario 1 or 2 . The two scenarios correspond to different accounting representations. We can draw a correspondence between scenario 2 , where a change in the value of the firm results from a change in net assets, and the current Conceptual Framework where income and expenses are defined in terms of changes in net assets not arising from transactions with owners in their capacity as owners. Under this view, an accounting concept of financial performance can be conformed to recognition in income and expenses: IFRS 9 sees both an impairment loss or gain and own risk gain or loss as financial performance, as such to be presented in profit or loss, although under certain circumstances presentation in OCI is used as a practical expedient to mitigate a counter-intuitive performance dilemma. A correspondence can also be drawn between scenario 1, where a 
change in the value of the firm results from a change in NOA, and a finance concept of financial performance that reflects changes in NOA. Under this view, as financial assets and financial liabilities are not part of NOA, there must be an accounting fallacy in recognizing those losses or gains as financial performance.

The accounting debate has been focusing on a false problem: defining the concept of financial performance with the aim of determining where to classify such gains or losses to conceal the counter-intuitive results issue instead of determining whether and when they really exist, but to date it has been unfruitful in determining the concept of financial performance. So, instead of seeking a definition of financial performance, the concept of value of the firm should lead what financial performance is supposed to represent. This article has moved from a finance view of this based on the MM paradigm to determine substance. The use of the two classifications in the article has confirmed that classification does not affect market valuation.

Such a classification is irrelevant and market participants may restate one scenario in terms of the other. Consequently, one of the two scenarios cannot exist under their view. This is a strong indication that market participants must consider scenario 1 as the scenario reflecting the MM paradigm, and A (i.e., the value of the firm) as represented by Net Operating Assets (NOA), only, not net assets. This also tells us that the Conceptual Framework definition of income and expenses based on net assets instead of NOA might be subject to revision.

\subsection{Contribution to Prior Research on Accounting Mismatch}

To the extent that classification of financial liabilities and financial assets is irrelevant, this contributes to prior literature in showing the fallacy of accounting mismatch, which arises from accounting classification conventions. IFRS 9 uses OCI in this occurrence as a plug to avoid accounting mismatch, and unlike U.S. GAAP (FASB ASC 825-10-45-6), IASB 2019, IFRS 9, para. B5.7.9 does not permit recycling the own credit risk component of $\mathrm{OCI}$ in profit or loss, even if the financial liability is derecognized and the credit risk becomes realized (IASB 2019, IFRS 9, para. BC5.54).

\subsection{Contribution to the Debate on Fulfilment Value versus Fair Value}

The above conclusions show that market participants would assess own risk (for Company 1) and an impairment (for Company 2) symmetrically. It is the issuer company that leads the valuation by market participants: irrespective of whether it is accepted that there is only an indirect effect or also a re-bounce effect (i.e., base versus alternative views), market participants will adjust their valuation of the holder company accordingly. Even at an accounting view, based on the model market participants value the effect of impairment on the holder company similarly to the effect of own risk on the issuer company (i.e., the absolute value of I equals R).

Conversely, as under IFRS 9 the accounting classification of a financial asset and a financial liability determines their measurement rules, the use of fair value for such liabilities and impairment rules for financial assets leads to asymmetry. This suggests exploring an analogy between impairment testing from the holder's perspective and fulfilment value (as newly defined in the IASB 2018, CF 2018) from the lender's perspective, and on the other hand the difference between fulfilment value and fair value. While the accounting effect of own credit risk for the issuer of a financial liability that is measured at FVTPL is based on fair value, impairment guidance for financial assets is based on criteria that are different from fair value. Impairment is an entity-specific assessment, guided by specific accounting provisions. It is not a theoretical basis, as fair value, but it very much incorporates real assumptions and expectations made by the reporting entity about an asset. Impairment testing is more reflective of what an informed party, with management eyes, would assume. Conversely, fair valuation, as an aseptic and theoretical measure, is a reconstruction of what it is assumed that market participants would value, taking insider information, company intentions and market imperfections aside. On the other hand, in a real world, market participants second-guess insider information by management in valuing a financial liability, including the counter party's impairment information, and use all information that is instead available or squeeze whatever indicator they can get hold of to get superior information, which might overwrite or adjust fair value measurement. This article shows that if the substance should be seen symmetrically for Company 1 and Company, fulfilment value rather than fair value might be more appropriate for such financial liabilities to reach a symmetry of valuation.

\subsection{Contribution to Prior Research on Incomplete Recognition of Contemporaneous Asset Value}

Finally, while for accounting purposes an economic relationship of a financial liability own risk with a non-qualifying asset is deemed to be different from one with a financial asset at fair value through profit or loss, they are alike under the application of MM theory, hence they should lead to like value of the firm. This goes in the same direction as some empirical evidence like in Cedergren et al. (2019). This contributes to prior empirical research about the effects of incomplete recognition of contemporaneous asset value changes in linking it to the 
accounting standards conventions that determine it. The IASB 2019, IFRS 9 qualification of an "economic relationship", which bars a non-financial asset, a financial asset not measured at fair value through profit or loss, or an unqualified accounting mismatch, distorts the value of equity while the application of MM theory would lead to the unvaried results.

\subsection{Theoretical Framework to Reconcile Accounting to MM Theory}

This paragraph provides a theoretical framework (Figure 1) about why accounting diverges from the outcomes obtained by applying a MM approach.

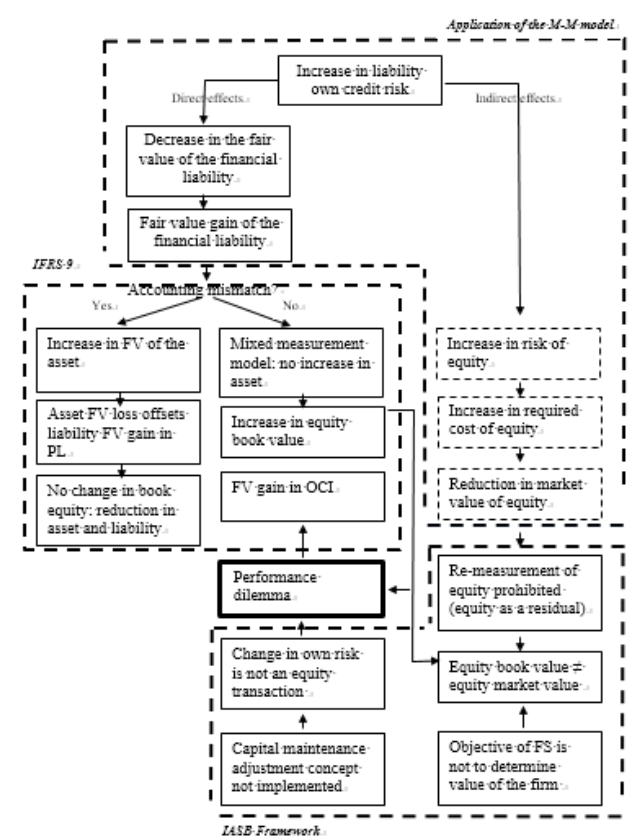

Figure 1. Theoretical framework to reconcile accounting to MM theory

In summary, if analyzed according to the MM theory, a change in a financial liability own credit risk has both an effect on equity through the direct measurement of the liability, and an effect due to the indirect change in equity risk. However, IASB 2019, IFRS 9 does not reflect the total change in the fair value of equity which comes from such a change in equity risk. This has several conceptual root causes, as follows.

This can be seen from two angles. The following arguments are first from the perspective of the unrecorded indirect and re-bound effects in equity.

IASB 2018, CF 2018, paras. 4.63, 6.88; IASB 2010, CF 2010, paras. 4.4(c), 4.22 and FASB 2008, CON 6, paras. 49 , Footnote $29,6.50,54,63,213,222$ have a prohibition on direct remeasurement of equity, derived from the concept of equity as a residual in the IASB and FASB Common Framework, where equity is assets less liabilities and is not subject to independent determination or remeasurement.

The concept of equity as a residual implies that the book value of equity does not, by definition, reflect its market value, unless a current value measure, e.g., fair value, were the only measurement attribute for all assets and liabilities, which is not the case in IFRS as well as in U.S. GAAP. This is also consistent with IASB and FASB Common Conceptual Framework, which states that determining the value of the entity is not the objective of the financial statements, although it suggests that the financial statements are also beneficial to the evaluation of a company (IASB 2018, CF 2018, paras. 1.2,1.7; IASB 2010, CF 2010, paras. OB2, OB7; CON 8, OB2, OB7).

On the other hand, the IASB discarded the alternative view to recognize changes in the credit risk of a financial liability in equity (IASB 2019, IFRS 9, para. BC5.44). It acknowledged that this notion has its roots into considering a change in a liability's credit risk as a wealth transfer between debt holders and equity holders (IASB 2010, ED/2010/4, para. BC33). In fact, IASB 2020, IAS 1 reserves recognition directly in equity only to changes in equity arising from contribution from, or distributions to, equity owners in their capacity as equity 
owners (IASB 2020, IAS 1, paras. IN2, IN13, 106, 109, BC37), but in this case there is no transactions with shareholders.

To date, the category of capital maintenance adjustments directly recognized in equity has not been used in IFRS, a concept which the Conceptual Framework reserves for gains and losses deriving from remeasuring assets and liabilities (IASB 2018, CF 2018, paras. 8.4, 8.7, 8.10; IASB 2010, CF 2010, paras. 4.20, 4.36, 4.60, 4.63). Capital maintenance adjustment might detect the indirect effects on equity of a change in liabilities own credit risk. The IASB took a position against presenting own risk gain or loss directly in equity (IASB 2019, IFRS 9, para. BC5.44.a).

Second, the following points are from the perspective of the recorded direct effect in equity.

While the MM theorem assumes that all assets and liabilities are at market values, IFRS and U.S. GAAP have chosen a mixed measurement attribute system (IASB 2018, CF 2018, paras. 6.1, 6.2; IASB 2010, CF 2010, paras. 4.54-4.55; FASB 2008, CON 5, paras. 66, 70), so the effect on book equity depends on the measurement bases of both assets and liabilities. For example, when there is no economic relationship, as defined in IFRS 9, but there is an otherwise unqualified accounting mismatch, book equity does not recognize the full adjustment of net assets to current values, simply because the asset has not been remeasured as not being carried at fair value. Only when there is an offsetting relationship as defined in IASB 2019, IFRS 9 whereby both changes in the fair value of financial assets and financial liabilities are recognized in the income statement, there will be a neutralization of the effects in equity.

Own credit risk accounting applies to certain financial liabilities that are measured at fair value. According to the IASB, these financial liabilities should be measured at fair value, hence the effects of a change in their credit risk should be considered part of an entity's performance and therefore be recognized in profit or loss (IASB 2019, IFRS 9, para. BC5.44). Unfortunately, this brings to a performance dilemma of counterintuitive effects on profit or loss, which made the IASB adopt OCI as a practical expedient. Some own credit risk gains or losses may be in profit or loss, others in OCI. In 2007 however, IASB 2020, IAS 1 para. 90 re-characterized OCI from a direct component of equity to an item of total comprehensive income, therefore an economic component. In the absence of a sound conceptual justification of what OCI is supposed to represent, as a complete and satisfactory theory of OCI has not been delivered yet, the debate of whether own risk should be part of performance has been widening.

In conclusion, if the MM theory is true (and it is generally held to be so), the system of equations shows that the recognition of own credit gain or loss for the financial liability issuer, as well as the corresponding impairment loss or gain for the financial asset holder, must be wrong from an economic perspective. Given the tenet that the accounting does not recognize shareholder wealth transfer, the current financial performance dilemma can be solved in two ways: either by recognizing in equity the concept of capital maintenance adjustment, or by using fulfillment value instead of fair value for such financial liabilities. In addition, if the MM theory is true, then the system of equations also shows that the definition of income in the Common Framework derived from changes in net assets as opposed to changes in net operating assets may also need to be revised. Consequently, the use of $\mathrm{OCI}$ as a way of drawing a separation at where financial performance ends, and consequently, the accounting mismatch are false problems, because there should be no gain or loss in profit or loss in the first place or wealth transfer should be recognized as a capital adjustment in equity.

\section{References}

Barth, M., Hodder, L., \& Stubben, S. (2008). Fair value accounting for liabilities and own credit risk. The Accounting Review, 83(3), 629-664. https://doi.org/10.2308/accr.2008.83.3.629

Bellandi, F. (2012). Dual reporting for equity and other comprehensive income under IFRS and U.S. GAAP. Chichester: John Wiley \& Sons Ltd.

Bischof, J., Daske, H., \& Sextroh, C. (2014). Fair value-related information in analysts' decision processes: evidence from the financial crisis. Journal of Business Finance \& Accounting, 41(3-4), 363-400. https://doi.org/10.1111/jbfa.12063

Bradbury, M. E. (2008). Issues in the drive to measure liabilities at fair value. Australian Accounting Review, 10(21), 19-25. https://doi.org/10.1111/j.1835-2561.2000.tb00059.x

Cardoso Fontes, J., \& Panaretou, A. (2018). The impact of fair value measurement for bank assets on information asymmetry and the moderating effect of own credit risk gains and losses. The Accounting Review, 93(6), 127-147. https://doi.org/10.2308/accr-52070_ 
Cedergren, M.C., Chen, C. \& Chen, K. (2019). The implication of unrecognized asset value on the relation between market valuation and debt valuation adjustment. Review of Accounting Studies, 24(1), 426-455. https://doi.org/10.1007/s11142-019-9486-2

Chasteen, L. G., \& Ransom, C. F. (2007). Including credit standing in measuring the fair value of liabilities Let's pass this one to the shareholders. Accounting Horizons, 21(2), 119:135.

Chung, S. G., Lobo, G., \& Yong, K. K. O. (2012). Valuation and risk implications of fair value accounting for liabilities: Evidence from FAS 159's reported gains and losses. Retrieved from https://www.researchgate.net/publication/330778775_Banks'_Discretion_over_the_Debt_Valuation_Adjust ment_for_Own_Credit_Risk. Accessed on 2020-03-02

Dong, M., Doukakis, L., \& Ryan, S. G. (2016). Banks' discretion over the debt valuation adjustment for own credit risk. https://doi.org/10.2139/ssrn.2920617

European Commission. Fourth Company Law Directive (Directive 78/660/EEC). (1978). https://eur-lex.europa.eu. Accessed on 2020-03-02.

European Financial Reporting Advisory Group (EFRAG). Pro-active Accounting Activities in Europe (PAAinE). (2008). Distinguishing between liabilities and equity. Discussion Paper. http://www.efrag.com. Accessed on 2020-03-02.

Financial Accounting Standards Board. (2008). Statement of Financial Accounting Concepts No. 5. Recognition and measurement in financial statements of business enterprises - as amended (CON 5). Retrieved from http://www.fasb.org

Financial Accounting Standards Board. (2008). Statement of Financial Accounting Concepts No. 6. Elements of financial statements - as amended (CON 6). Retrieved from http://www.fasb.org

Financial Accounting Standards Board. (2010). Statement of Financial Accounting Concepts No. 8. Conceptual framework for financial reporting - Chapter 1, The Objective of General-Purpose Financial Reporting, and Chapter 3, Qualitative Characteristics of Useful Financial Information (CON 8). Retrieved from http://www.fasb.org

Financial Accounting Standards Board. (2016). Accounting Standards Update No. 2016-01, Financial instruments - Overall (Subtopic 825-10) Recognition and measurement of financial assets and financial liabilities, (ASU 2016-02). Retrieved from http://www.fasb.org

Financial Accounting Standards Board. (2020). FASB Accounting Standards Codification (FASB ASC). http://www.fasb.org. Accessed on 2020-03-02.

Gaynor, L., McDaniel, L., \& Yohn, T. (2011). Fair value accounting for liabilities: the role of disclosures in unravelling the counterintuitive income statement effect from credit risk changes. Accounting Organizations and Society, 36, 125-134. https://doi.org/https://doi.org/10.1016/j.aos.2011.03.004

Heckman, P. E. (2004). Credit standing and the fair value of liabilities: a critique. North American Actuarial Journal. https://doi.org/10.1080/10920277.2004.10596161

International Accounting Standards Board. (2020). International Accounting Standard 1, Presentation of financial statements - as amended (IAS 1). Retrieved from http://www.ifrs.org

International Accounting Standards Board. (2008). Reducing complexity in reporting financial instruments. Discussion Paper (DP 2018). Retrieved from http://www.ifrs.org

International Accounting Standards Board. (2009). Credit Risk in Liability Measurement. Discussion Paper (DP/2009/2). Retrieved from http://www.ifrs.org

International Accounting Standards Board. (2010). Exposure Draft, Fair Value Option for Financial Liabilities (ED/2010/4). Retrieved from http://www.ifrs.org

International Accounting Standards Board. (2010). IFRS Conceptual framework. The conceptual framework for financial reporting 2010, Superseded (CF 2010). Retrieved from http://www.ifrs.org

International Accounting Standards Board. (2016). International Financial Reporting Standard 13, Fair value measurement - as amended (IFRS 13). Retrieved from http://www.ifrs.org

International Accounting Standards Board. (2018). IFRS Conceptual framework. Conceptual framework for financial reporting (CF 2018). Retrieved from http://www.ifrs.org

International Accounting Standards Board. (2018). International Accounting Standard 38, Intangible assets - as 
amended (IAS 38). Retrieved from http://www.ifrs.org

International Accounting Standards Board. (2019). International Financial Reporting Standard 9, Financial instruments - as amended (IFRS 9). Retrieved from http://www.ifrs.org

Lin, W., Panaretou, A., Pawlina, G., \& Shakespeare, C. (2019). What can we learn about credit risk from debt valuation adjustments? Retrieved from http://www.research.lancs.ac.uk/portal/en/publications.

Merton, R. C. (1974). On the pricing of corporate debt: the risk structure of interest rates. Journal of Finance, (29), 449-470. https://doi.org/10.1111/j.1540-6261.1974.tb03058.x

Modigliani, F., \& Miller, M. H. (1958). The cost of capital, corporation finance and the theory of investment. The American Economic Review, 48(3), 261-297. Retrieved from http://www.jstor.org/stable/1809766

\section{Copyrights}

Copyright for this article is retained by the author(s), with first publication rights granted to the journal.

This is an open-access article distributed under the terms and conditions of the Creative Commons Attribution license (http://creativecommons.org/licenses/by/4.0/). 